\title{
CHANGES IN THE HAEMOSTASIS SYSTEM OF PATIENTS WITH ALCOHOLIC CIRRHOSIS OF THE LIVER ASSOCIATED WITH NON-ALCOHOLIC FATTY LIVER DISEASE
}

\author{
Assosiate Professor Nataliia Matkovska \\ Ukraine, Ivano-Frankivsk, Ivano-Frankivsk National Medical University; \\ Department of Therapy and Family Practice of postgraduate study faculty
}

DOI: https://doi.org/10.31435/rsglobal_ws/30062019/6572

\section{ARTICLE INFO}

Received: 28 April 2019

Accepted: 23 June 2019

Published: 30 June 2019

\section{KEYWORDS}

alcoholic liver disease; non-alcoholic fatty liver disease; hemostasis.

\begin{abstract}
The purpose of the research was to study the changes in haemostatic system in patients with alcohol liver disease (ALD) associated with NAFLD. The decrease in the synthetic function of the liver and the development of hypersensitivity syndrome in patients with ALC in combination with NAFLD is accompanied by more pronounced changes in the various parts of the haemostasis of the corresponding Child-Pugh class, which manifests itself in the decrease in the number of blood corpuscles, PI levels, and growth of indicators for D-dimers, INR, Von Willebrand factor, PT, TT, APTT. Such changes lead to hypo- and hypercoagulation states, which may be accompanied by complications such as thrombosis and bleeding.
\end{abstract}

Citation: Nataliia Matkovska (2019) Changes in the Haemostasis System of Patients with Alcoholic Cirrhosis of the Liver Associated with Non-Alcoholic Fatty Liver Disease. World Science. 6(46), Vol.3. doi: 10.31435/rsglobal_ws/30062019/6572

Copyright: (C) 2019 Nataliia Matkovska. This is an open-access article distributed under the terms of the Creative Commons Attribution License (CC BY). The use, distribution or reproduction in other forums is permitted, provided the original author(s) or licensor are credited and that the original publication in this journal is cited, in accordance with accepted academic practice. No use, distribution or reproduction is permitted which does not comply with these terms.

Introduction. In recent years, the problems of pathogenesis, diagnostics and correction of disorders of the haemostasis system have attracted the attention of scientists more often. This is especially true for diseases that are accompanied by haemostasis disorders [1]. The liver affects on all components of haemostasis, it plays a significant role in regulation of this system, maintenance of the liquid state of the blood and keeping it within the vascular bed, by maintaining a balance between the thrombotic factors and the components responsible for blood flow. This balance is supported by the interaction of the coagulation cascade of platelets (blood coagulation system), vascular walls, and on the other hand - anticoagulative mechanisms and the fibrinolysis system [2, 3, 4]. Dystrophic and necrotic changes of hepatocytes, and especially such irreversible changes as disorders of the hepatic tissue architectonics, are the cause of the clinical and laboratory manifestation of the disease and determine the degree of severity and the rate of progression of the pathological condition $[5,6]$. In hepatocytes, all proteins of the coagulative system are synthesized; these are procoagulants (with the exception of the Von Willebrand factor and blood clotting factor VIII), coagulation inhibitors (antithrombin III, proteins C, S, $\alpha_{2}$-macroglobulin, $\alpha$-antitrypsin, etc.), [7, 8]. According to the literature, liver cirrhosis (LC) is characterized by a decrease in the number of such proteins in different proportions, which leads to an imbalance of procoagulants and anticoagulants. In this case, the more severe course of the disease correlates with a decrease in the number of inhibitors of coagulation, which causes the state of thrombophilia [9, 10, 11]. Therefore, researchers reveal both the states of hypocoagulation and hypercoagulation at the LC, which is the cause of intrahepatic and extrahepatic thromboses and leads to a steady progression of the LC and the development of fatal complications [12, 13, 14].

LC is one of the main causes of disability and mortality in economically developed countries [15]. The alcoholic etiology of the LC is the most common, however, in recent years, the problem of the growth of non-alcoholic fatty liver disease (NAFLD), which is accompanied by systemic disorders, in particular 
lipid and carbohydrate imbalances, has been widely studied. Such changes adversely affect the involvement of various systems and organs, as well as the growth rate of the disease progression and the development of multiple organ failure [16]. The risk of bleeding from varicose veins of the esophagus and the stomach, which is caused by a significant increase in pressure in the portal system due to the development of portal crises, dystrophic changes in the esophagus and stomach mucous membrane, and disorders in the haemostasis system, are considered to be a dangerous prognostic risk [17]. Therefore, it is important to study the various parts of the system of haemostasis and the possibility of correction of their disorders.

The purpose of the research was to study the changes in haemostatic system in patients with alcohol liver disease (ALD) associated with NAFLD.

Materials and methods. 204 patients with diagnosed LC participated in the study; they underwent inpatient treatment in the gastroenterology department of the Ivano-Frankivsk Regional Clinical Hospital. Among them, 78 patients were diagnosed with ALD at the stage of the LC (group I) and 126 patients had a combination of alcoholic liver cirrhosis (ALC) and NAFLD (group II). Among the patients in group I, there were 24 women and 54 men $(53.2 \pm 11.4)$ years old and average duration of the disease $(5.9 \pm 2.1)$ years; among patients of group II there were 22 women and 104 men (47.8 \pm 9.4$)$ years old and average duration of the disease $(4.2 \pm 2.7)$ years. Patients of groups I and II were subgrouped according to the compensation classes of LC by Child-Pugh score: IA (17 persons), IB (38 persons), IC (23 persons); IIA (44 persons), IIB (48 persons), IIC (34 persons). The body mass index (BMI) of patients in IA, IB, IC and IIA, IIB, IIC groups was (22.61 \pm 2.15$),(21.04 \pm 1.52),(19.21 \pm 1.63)$ and $(34.56 \pm 4.67),(30.83 \pm 2.87)$, $(21.35 \pm 1.63) \mathrm{kg} / \mathrm{m} 2$, respectively. Diagnosis was verified using clinical and laboratory-instrumental methods in accordance with the order of the Ministry of Health of Ukraine No. 826 dated November 6, 2014, adapted clinical guidelines "Non-Alcoholic Fatty Liver Disease", 2014, adapted clinical guidelines "Alcoholic Liver Disease", 2014, adapted clinical guidelines " Liver Cirrhosis, 2017 (State Expert Centre of the Ministry of Health of Ukraine, Ukrainian Gastroenterology Association, Kyiv), recommendations of the European Association for the Study of Liver, Diabetes and Obesity (EASL-EASD-EASO, 2016).

A general-clinical examination, ultrasound examination of the abdominal cavity and esophagogastroduodenoscopy were performed. To detect the alcoholic aetiology of the disease, according to the recommendations of the World Health Organization, more than 2 doses of alcohol ( 1 standard dose $=10 \mathrm{~g}$ of ethyl alcohol) per day for women and more than 4 doses for men, were taken into account. CAGE (Cut, Annoyed, Guilty, Eye-opener), AUDIT (Alcohol Use Disorders Identification Test, 1989), the PAS questionnaire (post-alcohol syndrome developed by P.P Ogurtsov, A.B. Pokrovsky, A.E Uspensky), LeGo (P.M LeGo 1976) in the modification of O.B. Zharkov, 2000), ANI index (Alcoholic liver disease/nonalcoholic fatty liver disease index, 2006) were used. The protein-synthetic function of the liver was determined by the level of albumin, fibrinogen in blood, prothrombin index (PI) and international normalized ratio (INR). Prothrombin time (PT), activated partial thromboplastin time (APTT), thrombin time (TT) and fibrinogen were measured using conventional methods. The content of plasmin degradation product of the insoluble D-dimer product fibrin (DD) was measured by immunoassay using "Technozym D-dimer ELISA", respectively ("Technoclone", Austria). Prothrombin time (PT), activated partial thromboplastin time (APTT), thrombin time (TT) and fibrinogen were measured using conventional methods. The Willebrand factor was determined by the method based on the stimulation of ristomycin aggregation (suspension of fixed donor platelets by the Willebrand factor of the study without platelet plasma). Calculation was carried out on a calibration curve built on logarithmic paper. For its construction, 20 donor platelet-poor plasmas were diluted $1: 1,1: 2,1: 4,1: 5$, corresponding to a concentration of $100 \%, 50 \%, 25 \%, 12.5 \%$ of the Willebrand factor in blood plasma. To increase the accuracy of the analysis, two parallel samples were tested, followed by an average value calculation. The control group included 20 practically healthy persons.

Exclusion criteria were liver cirrhosis of the viral, toxic and autoimmune genesis, metabolic diseases of the liver, oncological diseases, and the lack of individual consent of the patient to conduct the study. All patients were matched according to age and sex. The research was carried out in accordance with the ethical principles of conducting scientific research and principles of the Helsinki Declaration.

Statistical processing of the obtained results was carried out using the software package Statistica v. 12.0, StatSoft, USA and Microsoft Exel. The parameters of parametric statistics were used - the arithmetic average (M) and the standard deviation (SD). To determine the significance of the differences between groups in the distribution, close to normal, t-criterion Student was used. Statistically significant differences were considered at $\mathrm{p}<0.05$.

Research results. Analyzing the data of the clinical examination, it was found that the symptoms of astheno-vegetative, painful, dyspeptic, hepatorenal, hepatopulmonary syndromes, jaundice, medically uncontrolled ascites, signs of hepatic encephalopathy were more common in patients of group II of the corresponding classes. Among hemorrhagic complications there was 
bleeding from esophageal varices. 19 (31.1\%) and 31 (37.8\%) persons of IB (8/21.1) + C (11/47.8) and IIB (12/25) + C (19/55.9) groups respectively, suffered from bleeding esophageal varices.

Splenomegaly syndrome was clinically manifested by an increase in the size of the spleen in $58.8 \%, 75 \%, 71.1 \%, 89.6 \%$ of patients of IA, IIA, IB, IIB groups, respectively, and in all patients of IC and IIC groups. Laboratorially, the splenomegaly syndrome was manifested by a decrease in the number of platelets and erythrocytes. In patients of group II, such changes were more pronounced (Table 1).

The results of the biochemical study showed that the parameters of the synthetic function of the liver in patients of Group II was more pronounced decrease compared to patients in Group I, which is reflected in lowering the albumin content in the blood, fibrinogen and PI (IIA - by 9.1\%, 9.1\%, 5.5\%, 13.4\%, IIC - by $12.5 \%, 19.2 \%, 9.6 \%, 15.1 \%$, IIC - by $16.1 \%, 14.3 \%, 9.1 \%, 9.9 \%$ respectively, all $\mathrm{p}<0.05)$.

The content of D-dimers was higher in patients of group II than in patients of group I for Child-Pugh class A - by $11.11 \%(\mathrm{p}<0.05)$; class B - by $16.67 \%(\mathrm{p}<0.05)$, and did not differ significantly in the terminal stage of ALC for C class ( $p>0.05$ ). The levels of INR increased with increasing decompensation of ALC $(\mathrm{p}<0.05)$, which indicates liver dysfunction; its differences in patients of both groups were not detected $(\mathrm{p}>0.05)$.

The number of platelets decreased with the progression of the disease and was lower in patients of IIA, IIB and IIC groups by $25.5 \%, 19.5 \%$ and $24.2 \%$, respectively, compared to patients in group I of the corresponding classes. The number of erythrocytes also decreased with decompensation of the disease and was lower in patients of IIA, IIB and IIC groups by 5.3\%, 19.5\% and 14.5\%, respectively, compared to patients in group I of the corresponding classes.

Level of Von Willebrand factor increases with progression of the disease. In particular, in patients of IIA, IIB and IIC groups, this indicator was higher by $10.7 \%, 22.7 \%$ and $10.5 \%$, respectively, compared with patients in group I of the corresponding classes.

Indicators of PT, APTT and TT increased with progression of the disease. In patients of IIA, IIB and IIC groups, the levels of PT were 16.1\%, 13.8\% and 11.5\% higher than those in patients of group I of the corresponding classes. Indicators of APTT in patients of IIA, IIB and IIC groups was $9.5 \%, 17 \%$ and $24.2 \%$ higher than those in group I of the corresponding classes. TT values in patients of IIA, IIB and IIC groups were $9 \%, 10.1 \%$ and $7.5 \%$ higher than those in group I of the corresponding classes.

Table 1. Indicators of the synthetic function of the liver and disorders of haemostatic system in patients with alcoholic liver cirrhosis depending on the concomitant non-alcoholic fatty liver disease and Child-Pugh class, $\mathrm{M} \pm \mathrm{m}$

\begin{tabular}{|c|c|c|c|c|c|c|c|}
\hline \multirow{2}{*}{$\begin{array}{l}\text { Parameters } \\
(\text { Mean } \pm \text { SD) }\end{array}$} & \multirow{2}{*}{$\begin{array}{c}\text { Healthy } \\
n=20\end{array}$} & \multicolumn{2}{|c|}{ Class A } & \multicolumn{2}{|c|}{ Class B } & \multicolumn{2}{|c|}{ Class C } \\
\hline & & $\begin{array}{c}\text { Group I, } \\
\mathrm{n}=17\end{array}$ & $\begin{array}{c}\text { Group II, } \\
n=44\end{array}$ & $\begin{array}{c}\text { Group I, } \\
\mathrm{n}=38\end{array}$ & $\begin{array}{c}\text { Group II, } \\
\mathrm{n}=48\end{array}$ & $\begin{array}{c}\text { Group I, } \\
n=23\end{array}$ & $\begin{array}{l}\text { Group } \\
\text { II, n=34 }\end{array}$ \\
\hline Total protein, $\mathrm{g} / \mathrm{l}$ & $\begin{array}{c}74.67 \pm \\
4.27\end{array}$ & $\begin{array}{l}62.12 \pm \\
5.74^{*}\end{array}$ & $\begin{array}{l}59.92 \pm \\
2.56^{*}\end{array}$ & $\begin{array}{l}56.46 \pm \\
2.24 * \diamond\end{array}$ & $\begin{array}{l}52.72 \pm \\
2.16^{* \diamond}\end{array}$ & $\begin{array}{c}46.35 \pm \\
2.71^{* \bullet} \#^{\circ}\end{array}$ & $\begin{array}{l}42.18 \pm \\
1.53^{*} \#^{\circ}\end{array}$ \\
\hline Albumin, $\mathrm{g} / \mathrm{l}$ & $\begin{array}{c}47.83 \pm \\
4.26\end{array}$ & $\begin{array}{l}43.37 \pm \\
1.86^{* \bullet}\end{array}$ & $\begin{array}{c}39.43 \pm \\
1.09 *\end{array}$ & $\begin{array}{l}34.61 \pm \\
1.75^{* \bullet \diamond}\end{array}$ & $\begin{array}{l}30.28 \pm \\
1.58 * \diamond\end{array}$ & $\begin{array}{c}28.82 \pm \\
1.74^{* \bullet} \#^{\circ}\end{array}$ & $\begin{array}{l}24.17 \pm \\
1.65^{* \#^{\circ}}\end{array}$ \\
\hline Fibrinogen, g/L & $\begin{array}{c}3.66 \pm \\
0.27\end{array}$ & $\begin{array}{l}2.74 \pm \\
0.09^{*}\end{array}$ & $\begin{array}{l}2.49 \pm \\
0.07^{*}\end{array}$ & $\begin{array}{c}2.14 \pm \\
0.12^{* \bullet \diamond}\end{array}$ & $\begin{array}{l}1.73 \pm \\
0.14^{* \diamond}\end{array}$ & $\begin{array}{c}1.61 \pm \\
0.13^{* \bullet} \#^{\circ}\end{array}$ & $\begin{array}{c}1.38 \pm \\
0.11^{* \#^{\circ}}\end{array}$ \\
\hline $\begin{array}{l}\text { Erythrocytes, } * 10 \\
12 / 1\end{array}$ & $\begin{array}{c}4.68 \pm \\
0.31\end{array}$ & $\begin{array}{l}4.16 \pm \\
0.36\end{array}$ & $\begin{array}{l}3.95 \pm \\
0.34^{*}\end{array}$ & $\begin{array}{l}3.85 \pm \\
0.27^{* \bullet}\end{array}$ & $\begin{array}{l}3.22 \pm \\
0.25 * \diamond\end{array}$ & $\begin{array}{c}2.45 \pm \\
0.14^{* \bullet} \#^{\circ}\end{array}$ & $\begin{array}{l}2.14 \pm \\
0.13^{* \#}\end{array}$ \\
\hline Platelets, $* 10^{9} / 1$ & $\begin{array}{c}254.13 \pm \\
15.63\end{array}$ & $\begin{array}{l}204.38 \pm \\
12.72 * \bullet\end{array}$ & $\begin{array}{c}162.43 \pm \\
10.34^{*}\end{array}$ & $\begin{array}{l}153.29 \pm \\
9.78^{* \bullet \diamond}\end{array}$ & $\begin{array}{l}128.31 \pm \\
10.23 * \diamond\end{array}$ & $\begin{array}{l}116.94 \pm \\
7.36^{* \bullet} \#^{\circ}\end{array}$ & $\begin{array}{l}94.15 \pm \\
8.87^{*} \#^{\circ}\end{array}$ \\
\hline $\begin{array}{l}\text { Von Willebrand } \\
\text { factor, } \%\end{array}$ & $\begin{array}{c}102.31 \pm \\
4.51\end{array}$ & $\begin{array}{c}115.82 \pm \\
5.26^{*}\end{array}$ & $\begin{array}{c}128.19 \pm \\
6.31 *\end{array}$ & $\begin{array}{l}137.26 \pm \\
4.95^{* \bullet} \diamond\end{array}$ & $\begin{array}{l}168.37 \pm \\
5.26 * \diamond\end{array}$ & $\begin{array}{l}197.52 \pm \\
7.41^{* \bullet} \#^{\circ}\end{array}$ & $\begin{array}{l}218.34 \pm \\
6.07 * \#^{\circ}\end{array}$ \\
\hline PT (sec) & $\begin{array}{c}11.27+ \\
0.69\end{array}$ & $\begin{array}{l}12.62 \pm \\
0.71 *\end{array}$ & $\begin{array}{l}14.65 \pm \\
0.84 * \bullet\end{array}$ & $\begin{array}{l}15.09 \pm \\
0.67 * \diamond\end{array}$ & $\begin{array}{l}17.18+ \\
0.72 * \bullet \diamond\end{array}$ & $\begin{array}{c}19.84 \pm \\
0.75^{*} \#^{\circ}\end{array}$ & $\begin{array}{c}22.12+ \\
0.86^{*} \bullet \#^{\circ}\end{array}$ \\
\hline APTT (sec) & $\begin{array}{c}27.76 \pm \\
1.35\end{array}$ & $\begin{array}{l}33.07 \pm \\
1.38^{*}\end{array}$ & $\begin{array}{l}36.21 \pm \\
1.53^{*}\end{array}$ & $\begin{array}{l}36.84 \pm \\
1.62 * \diamond\end{array}$ & $\begin{array}{l}43.12 \pm \\
1.97 * \bullet\end{array}$ & $\begin{array}{l}44.63 \pm \\
1.71 * \#^{\circ}\end{array}$ & $\begin{array}{c}55.42 \pm \\
2.13^{* \bullet} \bullet \#^{\circ}\end{array}$ \\
\hline TT $(\mathrm{sec})$ & $\begin{array}{c}16.79 \pm \\
0.82\end{array}$ & $\begin{array}{c}18.56 \pm \\
0.73^{*}\end{array}$ & $\begin{array}{c}20.24 \pm \\
0.85^{*}\end{array}$ & $\begin{array}{l}21.46 \pm \\
0.94 * \diamond\end{array}$ & $\begin{array}{l}23.67 \pm \\
1.19 * \bullet \diamond\end{array}$ & $\begin{array}{l}23.91 \pm \\
1.27^{*} \#^{\circ}\end{array}$ & $\begin{array}{l}25.71 \pm \\
1.24^{*} \#^{\circ}\end{array}$ \\
\hline INR & $\begin{array}{l}1.21 \pm \\
0.08\end{array}$ & $\begin{array}{l}1.34 \pm \\
0.07 * \bullet\end{array}$ & $\begin{array}{l}1.52 \pm \\
0.12 *\end{array}$ & $\begin{array}{c}1.85 \pm \\
0.11^{* \bullet \diamond}\end{array}$ & $\begin{array}{c}2.13 \pm \\
0.09 * \diamond\end{array}$ & $\begin{array}{c}2.51 \pm \\
0.14^{* \bullet} \#^{\circ}\end{array}$ & $\begin{array}{c}2.76 \pm \\
0.10^{*} \#^{\circ}\end{array}$ \\
\hline PI, \% & $\begin{array}{c}88.52 \pm \\
5.73\end{array}$ & $\begin{array}{l}75.58 \pm \\
1.34^{* \bullet}\end{array}$ & $\begin{array}{c}71.43 \pm \\
1.47 * \\
\end{array}$ & $\begin{array}{c}62.27 \pm \\
1.99 * \bullet\end{array}$ & $\begin{array}{l}56.32 \pm \\
1.58 * \diamond\end{array}$ & $\begin{array}{c}38.18 \pm \\
1.86^{* \bullet} \#^{\circ}\end{array}$ & $\begin{array}{c}34.71 \pm \\
1.42^{*} \#^{\circ}\end{array}$ \\
\hline D-dimer, $\mathrm{ng} / \mathrm{ml}$ & $\begin{array}{c}0.29 \pm \\
0.01\end{array}$ & $\begin{array}{l}0.45 \pm \\
0.01 *\end{array}$ & $\begin{array}{c}0.50 \pm \\
0.01 * \bullet\end{array}$ & $\begin{array}{c}0.60 \pm \\
0.03 * \diamond\end{array}$ & $\begin{array}{c}0.72 \pm \\
0.04 * \bullet \diamond\end{array}$ & $\begin{array}{c}0.84 \pm \\
0.04 * \#^{\circ}\end{array}$ & $\begin{array}{c}0.95 \pm \\
0.06^{*} \bullet \#^{\circ}\end{array}$ \\
\hline
\end{tabular}


Notes: * - the reliability of the differences between Groups II and I compared with healthy persons, $\bullet$ - the reliability of the indicators difference in Group I compared with Group II of the corresponding Child-Pugh Classes, $\diamond$ - the reliability of the indicators difference of Class B compared with Class A in Groups II and I, respectively, p<0.05; \# - the reliability of the indicators difference of Class C compared with Class A in Groups II and I, respectively, $\mathrm{p}<0.05$; $^{\circ}$ the reliability of the indicators difference of Class C compared with Class B in Groups II and I, respectively, $\mathrm{p}<0.05$.

Thus, a decrease in the synthetic function of the liver and the development of hypersensitivity syndrome in patients with ALC in combination with NAFLD is accompanied by more pronounced changes in the various parts of the haemostasis of the corresponding Child-Pugh class, which manifests itself in the decrease in the number of blood corpuscles, PI levels, and growth of indicators for D-dimers, INR, Von Willebrand factor, PT, TT, APTT. Such changes lead to hypo- and hypercoagulation states, which may be accompanied by complications such as thrombosis and bleeding.

Conclusions. Patients with ALC associated with NAFLD have more pronounced changes in various haemostasis stages: procoagulant and anticoagulant factors. In particular, the levels of PI and blood corpuscles decrease, while the D-dimers, INR, Von Willebrand factor, PT, TT, and APTT indices are increasing.

\section{REFERENCES}

1. Intagliata NM, Davis JPE, Caldwell SH. Coagulation Pathways, Hemostasis, and Thrombosis in Liver Failure. Semin Respir Crit Care Med 2018; 39:598.

2. Bos S, van den Boom B, Kamphuisen PW, Adelmeijer J, Blokzijl H, Schreuder T, Lisman T. Haemostatic profiles are similar across all aetiologies of cirrhosis. Thromb Haemost. 2019; 119 (2): 246-253.

3. Vinholt PJ, Hvas AM, Nielsen C, Söderström AC, Sprogøe U, Fialla AD, Nybo M. Reduced platelet activation and platelet aggregation in patients with alcoholic liver cirrhosis. Platelets. 2018 Jul; 29 (5): 520-527.

4. Тугушев А. С., Михантьев Д. И., Нешта В. В., Черковская О. С., Рязанова Е. Д. Коррекция системы гемостаза у больных циррозом печени. Запорожский медицинский журнал. 2015. №5 (92): 45-47.

5. Potze W, Siddiqui MS, Boyett SL, Adelmeijer J, Daita K, Sanyal AJ, Lisman T. Preserved hemostatic status in patients with non-alcoholic fatty liver disease. J Hepatol. 2016 Nov; 65(5): 980-987.

6. Anna K. Kopec, Nikita Joshi, James P. Luyendyk. Role of hemostatic factors in hepatic injury and disease: Animal models de-liver. J Thromb Haemost. 2016 Jul; 14 (7): 1337-1349.

7. Kalambokis GN, Oikonomou A, Christou L et al. Von Willebrand factor and procoagulant imbalance predict outcome in patients with cirrhosis and thrombocytopenia. J Hepatol. 2016; 65: 921.

8. Yilmaz, VT, Dincer D, Avci AB, Cetinkaya R. Significant Association between Serum Levels of von Willebrand Factor (vWF) Antigen with Stages of Cirrhosis. The Eurasian Journal of Medicine. 2015; 47(1): 21-25.

9. Hugenholtz GC, Macrae F, Adelmeijer J, et al. Procoagulant changes in fibrin clot structure in patients with cirrhosis are associated with oxidative modifications of fibrinogen. J Thromb Haemost 2016; 14: 1054.

10. Fisher C, Patel VC, Stoy SH et al. Balanced haemostasis with both hypo- and hyper-coagulable features in critically ill patients with acute-on-chronic-liver failure. J Crit Care. 2018; 43: 54.

11. Intagliata NM, Argo CK, Stine JG et al. Concepts and Controversies in Haemostasis and Thrombosis Associated with Liver Disease: Proceedings of the 7th International Coagulation in Liver Disease Conference. J Thromb Haemost. 2018; 118: 1491.

12. Blasi A, Calvo A, Prado V, et al. Coagulation Failure in Patients With Acute-on-Chronic Liver Failure and Decompensated Cirrhosis: Beyond the International Normalized Ratio. Hepatology 2018; 68:2325.

13. Хурум 3. Ю., Кулбужева М. И., Кончакова А. А. Кровотечение из варикозно-расширенных вен пищевода при циррозе печени. Кубанский научный медицинский вестник. 2017. №2 (163): 135-138.

14. Budimir I, Gradišer M, Nikolić M, Baršić N, Ljubičić N, Kralj D, Budimir I Jr. Glasgow Blatchford, preendoscopic Rockall and AIMS65 scores show no difference in predicting rebleeding rate and mortality in variceal bleeding. Scand J Gastroenterol. 2016 Nov; 51 (11): 1375-9.

15. Bos S, Potze W, Siddiqui MS, Boyett SL, Adelmeijer J, Daita K, Lisman T, Sanyal AJ. Changes of in vitro potency of anticoagulant drugs are similar between patients with cirrhosis due to alcohol or nonalcoholic fatty liver disease. Thromb Res. 2017 Feb; 150: 41-43.

16. Potze W, Siddiqui MS, Sanyal AJ. Vascular Disease in Patients with Nonalcoholic Fatty Liver Disease. Semin Thromb Hemost. 2015 Jul; 41 (5): 488-93.

17. Stine JG, Niccum BA, Zimmet AN et al. Increased risk of venous thromboembolism in hospitalized patients with cirrhosis due to non-alcoholic steatohepatitis. Clin Transl Gastroenterol. 2018; 9: 140. 